\title{
Factors for success in biotechnology: Then and now
}

\section{To launch a successful startup, keep your focus on the basics.}

\author{
Steven Gillis
}

As a scientist, I have had the good fortune, misfortune, self-confidence, and naiveté to be associated with the founding of two public biotechnology companies. The first company, Immunex (Seattle, WA), was founded in 1981, in what might now be considered to be the prehistoric dawn of biotechnology. The second, Corixa (Seattle, WA), was formed 13 years later, well after the birth of some 1,200 other like-minded concerns.

The times associated with the start of each company were clearly different, as were the hurdles one needed to clear to raise capital, find facilities, and hire staff. The requirements of company management were markedly different and the rigor with which investors viewed proposed scientific and business plans, radically altered. Nevertheless, I believe there are common themes between these two eras that are essential prerequisites for the formation of any successful technology-based company.

\section{A world without limits?}

Immunex was formed when people were clearly only dreaming of the potential uses of recombinant DNA technology. With respect to immune system hormones, not a single interleukin gene had been cloned by 1981 . No cytokine had actually been purified to molecular homogeneity.

As a result, there was nothing in the way of preclinical efficacy data in animals or, perish the thought, clinical data to review so that investors could gauge the likelihood of the commercial success of an Immunex startup. The most reliable source of funding, the venture capital community, knew little, if anything, about biotechnology. What they did know came mainly from reading Scientific American or trade journals in the healthcare arena, if you weren't working on recombinant insulin or interferon-the two leading biotechnology innovations in the late 1970 s - the perception was that you had missed the boat.

Steven Gillis is president and CEO of Corixa Corp., 1124 Columbia Street, Suite 200, Seattle,WA 98104 (gillis@corixa.com).
Naiveté was a wonderful catalyst for the birth of the biotechnology revolution. Scientist entrepreneurs knew little of the technological pitfalls associated with recombinant DNA and the expression of foreign proteins in microbial or mammalian cells.

There was little competition for investor support. What was important was convincing investors that healthcare applications of recombinant DNA technology was where they were likely to make money. As I remember it, the competition consisted of projects that involved creating a new breed of supercorn, oil-eating bacteria, or organisms that could produce ice crystals above 32 degrees, allowing ski resorts to make deep powder when nature wouldn't cooperate.

When it came to management, investors couldn't rely on the past commercial achievements of founder entrepreneurs. There weren't any. As a result, what they could rely on was only the academic and scientific track records of the founding scientists and "hunches." If the technology base seemed reasonable and the founders credible, they supported the development of the company.

About the only business plans that were shunned were so-called one-product-wonder businesses. Broader approaches that focused on major unmet medical and commercial needs were favored.

Neither investors nor entrepreneurs paid much attention to whether the focus was on licensing one's inventions to third parties for presumed massive upfront payments and royalties or on attempting to build a fully integrated drug company-something that had not been done in the post-World War II era since the creation of Syntex, whose fortunes were built on oral contraceptives and Naprosyn.

In general, the conviction on both sides of the negotiating table was that we were at the beginning of a technological revolution. Good things were destined to happen. Much like the history of various Western gold rush- es, it seemed that prospectors and bankrollers alike were not concerned with whether they would stake a claim; the only issues were how soon and how large.

In short, naiveté was a wonderful catalyst for the birth of the biotechnology revolution. Scientist entrepreneurs knew little of the technological pitfalls associated with recombinant DNA and the expression of foreign proteins in microbial or mammalian cells. Likewise, investors had little appreciation for the rigors of clinical trials, the politics of Food and Drug Administration (Rockville, MD) advisory panels, and the massive impact that these vagaries would play on their rate of return calculations, as well as on the marketability and viability of the companies they were founding.

\section{An intensely competitive playground}

By 1994, the relaxed naiveté of the earlier era had given way to the frenetic cynicism that accompanies an industry that knows there will be winners and losers. There were a number of very good reasons for this. The field had learned of the perils associated with the dreaded word "scale-up," with the realization that the fermentation and purification protocols used for making recombinant proteins at the lab bench were often useless for producing reproducible lots of commercial or clinical product.

Countless companies learned the hard way that the first patient in every clinical trial is always a responder, and that clinical trial results viewed against a backdrop of historical controls are always more impressive than data obtained in a prospective, randomized, and blinded study.

The investment community, in particular, had grown increasingly cynical, toughened by too few product successes and too many product restarts or failures. While a whole lot of money had been made in biotechnology, a fair amount had also been lost. In addition, venture capitalists were getting far greater returns on investment, without regulatory authority risk, in information technology and Internet companies. All of these factors made the hurdles to clear for investment, particularly sizable investment, that much higher. 
Where once good science was enough to attract investors, now founding management needed relevant and successful industry experience. Where once business philosophies and approaches to downstream return could be dealt with later, successful 1994 biotechnology startups needed a complete and bulletproof business strategy. The goal of becoming a fully integrated company was illusory, and received cynical and pessimistic investor criticism. There was far too much competition.

Managed care, healthcare reform, and huge pharmaceutical company mergers had erected an even larger barrier to small company entry than ever before. The only apparent successful strategy was to fashion oneself as a partnering or platform company, whose technology could be sold multiple times to multiple partners for premium returns.

As a result, venture capitalists had developed an almost cookie-cutter approach to financing. Companies would be started for as little seed capital as possible. A formal financing in the range of $\$ 3-5$ million would take place later, together with a promise for further needed financing based on management's successful achievement of a variety of technical and commercial milestones.

It was into this background that Corixa stepped with a business plan calling for a $\$ 15$ million initial round of equity financing. Seeking its first venture capital funding, investor sentiment was close to an all-time low. The proverbial window wasn't just closed; It was nailed shut and bricked over. But Corixa was fortunate in having a solid platform technology and in being able to weave that technology into a research and business plan that could command financing even in the toughest of markets. Since that time, Corixa has grown in size to some 110 full-time employees and has diversified its development risk over more than a dozen funded corporate partnerships. When the window of public financing opened briefly in 1997, we jumped through, raising an additional $\$ 45$ million in equity capital on the strength of our partnering and platform technology achievements.

\section{Battle-tested lessons}

Having helped start two very different biotechnology companies in two very different scientific, financial, and commercial time frames, it is possible to find some common themes that might be of use to today's scientific entrepreneur who feels he or she must join the even more competitive marketplace that lies ahead. While some of what follows might strike you as obvious, it is surprising how many of today's startup's business plans remain deficient with respect to one or more of the following attributes:

First, make sure your founding technolo- gy can be configured into, or used to generate, multiple products. One-product wonders were shunned in 1981 and are scorned in 1998. Investors favor "platforms" of technology that have the potential to throw off multiple product lines.

Second, make certain that your technology can be protected. Determining that the technology is patentable is no longer enough. You need to ensure that once patented, you will be free to operate in the marketplace. In other words, you need to know that you don't need a license from some other patent holder in order to practice your invention.

Third, if you don't have relevant experience in the industry, attract someone to the management team who does. There are now literally thousands of experienced managers and executives who have helped shape the

\section{Make sure your founding technology can be config- ured into, or used to gener- ate, multiple products. One-product wonders were shunned in 1981 and are scorned in 1998.}

biotechnology industry. Whether scientists, accountants, attorneys, or businesspeople, any proposed management team needs a couple of veterans on the roster.

Fourth, have a clear idea of how your company will manufacture, market, test, and sell its products. The barriers to commercial entry from a startup are huge. Any business idea worthy of funding needs a well thought out plan as to who is going to pay for the company's product development, and more importantly, who will buy the products.

Significant effort needs to be made before the first meeting with investor number one to make sure that all product licenses needed by management are secured or available on favorable economic terms. Don't wait until the due diligence process to answer such tough questions as how much your products will cost and how much the market (insurers, patients, etc.) will be willing to pay for them.

Fifth, make sure that the products that will come from your technology address a real unmet need of economic significance. Entrepreneurs need to present real data on the magnitude of the economic problem they are going to solve with the wonders of their technology. If, for example, their products address significant health problems that exist only in countries where currencies cannot be recognized by US investors, management needs to rethink its business focus. If the technology provides only a modest improvement over present-day methodology for treatment or diagnosis, do not be surprised if investors view the opportunity with disdain.

Sixth, figure out how much money you need to raise and then multiply it by some factor (a percentage ranging from $20-100 \%$ ). There is no such thing as an overcapitalized company. Too many companies are founded on day one, only to realize that they are undercapitalized on day two. Such entities are forced into accepting business transactions with less-than-desirable terms to keep the lights on or to cross a business milestone and become eligible for a later round of financing. Do yourself a big favor and sell more of the company initially at a lower price. While you may hate yourself in the morning, at least you'll have more mornings.

Seventh, in raising money for your company, worry far less about how much you and your cofounders' shares will be diluted as a result of the financing. The primary concern is to raise money to ensure the company's success-not your own.

Finally, keep your message simple. Your initial business plan and research objectives should focus on making sure that one application of your technology is a success. Pursuing all applications at once will increase the odds that none of them will succeed.

\section{Conclusions}

While the environment for starting and running a biotechnology company has changed dramatically since the early 1980s, the basic principles of making it a success remain the same. Having been through both a very tough time for financing and a relatively easy one, my advice to bioentrepreneurs is to embrace the technology surrounding your business venture and make sure it has the potential to create multiple lines of products. Build a credible business plan based on the product opportunity that is most likely to succeed. Construct a well-documented and market-endorsed plan for product commercialization that takes into account the real medical or agricultural, and importantly, economic need for the products you will invent. Know what the competition is, how you will outmaneuver them, or if necessary, what licenses are required for your products' and your company's viability. Hire the best and hardest working management you can, always looking for individuals who have credible and successful prior track records in the biotechnology arena. Avoid the pitfalls of perennial undercapitalization, and once the money is raised, focus on delivering that first milestone or product opportunity as fast as you can. Never let your ego stand in the way of providing an excellent return for your stakeholders. Good luck! 